\title{
Making ideas actionable in institutionalism: the case of trade liberalization in Kennedy's foreign economic policy
}

\author{
Mark McAdam ${ }^{1,2 *}$ \\ ${ }^{1}$ University of Siegen, School of Economic Disciplines, Kohlbettstr. 17, 57078 Siegen, Germany and ${ }^{2}$ Witten/Herdecke \\ University, Faculty of Management, Economics and Society, Alfred-Herrhausen-Str. 50, 58448 Witten, Germany \\ *Corresponding author. Email: mark.mcadam@uni-siegen.de
}

(Received 14 November 2020; revised 30 October 2021; accepted 4 November 2021; first published online 7 December 2021)

\begin{abstract}
This article challenges exclusively rationalist accounts of and offers a complementary explanation for the emergence of liberal trade policy in the Kennedy administration. I draw on recent insights in constructivist institutionalism to emphasize the need to take agency seriously in institutionalist research. Using archival records, I analyze the decisive role Kennedy's advisers played as carriers of ideas in advocating for liberal trade policy by 'constructing the national interest', thus convincing a reticent president to support attempts aimed at achieving closer economic integration, culminating in the Trade Expansion Act of 1962. Insights from their role as advisers can help in specifying the role of agency in the ideas and institutional change literature, through strategic action which shaped a political leader's belief and put political issues on the agenda. By grasping agency in terms of making ideas actionable, an important step is taken in advancing endogenous approaches of institutional change.
\end{abstract}

Key words: Agency; constructivist institutionalism; foreign economic policy; historical institutionalism; ideas; institutions; trade liberalization

\section{Introduction}

It is obvious, however, that there is keen awareness on the part of the President of the fact that... the tide is running in a protectionist direction (Viner, 1961: 565).

We are at a dead end with our present trade policy legislation. The Trade Agreements Act has been so amended and the atmosphere surrounding it has become so restrictive as to deprive us of almost all maneuver room... This is our situation at a time of revolutionary change in the trading world that we have known...If we can move forward aggressively, the major trading nations will follow, for the most part, willingly and readily...Our opposing choice...[is] to present ourselves to the world at large as inward-looking and fearful of the future (Memorandum, anon., 1961: 1-3).

Why were the 1960s a period of further economic integration and American trade liberalization following the passage of the Trade Expansion Act (TEA) of 1962 and the Kennedy Round of the General Agreement on Tariffs and Trade (GATT), when the conditions at the time were not amenable to such reform? The quote above by Jacob Viner highlights the zeitgeist when John F. Kennedy assumed office in January 1961. Yet at a time at which trade liberalization was being viewed increasingly skeptically, the Kennedy administration nevertheless pursued some of the most far-reaching trade liberalization the country had known. That this occurred at a time during which 'the tide was running in the opposite direction' constitutes the puzzle of American trade policy early in the decade.

(C) The Author(s), 2021. Published by Cambridge University Press on behalf of Millennium Economics Ltd. This is an Open Access article, distributed under the terms of the Creative Commons Attribution licence (https://creativecommons.org/licenses/by/4.0/), which permits unrestricted re-use, distribution, and reproduction in any medium, provided the original work is properly cited. 
In contrast to approaches focusing exclusively on 'power' and 'incentives', I argue that strictly rationalist accounts of this time period face crucial shortcomings and suggest that explanations based on such concepts alone are themselves incomplete in explaining further economic integration. I contend that ideas by policy advisers surrounding Kennedy played a critical role in leading to further trade liberalization, and that these must be taken into account to understand the changes in trade policy in the 1960s. My argument is consonant with scholarship in the past decades which has paid increasing attention to the role that ideas play in their impact on policy outcomes, but which has only recently shifted its focus to the role that individuals - as the carriers of ideas - play (see Alston, 2017; Béland and Cox, 2016; Carstensen, 2011; Couyoumdjian and Larroulet, 2018; Köstem, 2017; Morrison, 2012; Schmidt, 2017).

This article is structured as follows: first, I explore the political economy of the early 1960s, highlighting changes that had occurred within the political landscape which made further economic integration unlikely. Second, I examine competing rationalist explanations for American trade liberalization which invoke a determinacy of liberal policy. Congruent with the recognition by some rational choice scholars, such as Ronald Rogowski (1989: 126-127), that exclusively rationalist explanations neglect important factors, third, I suggest that taking seriously the ideas of Kennedy's advisers promises to shed light onto the puzzle of economic integration in his presidency. I embed this case study within scholarship on ideas and institutions (see Berman, 1998; Blyth, 2002; Goldstein, 1993; Hall, 1989; Hay, 2006; Markey-Towler, 2019; McCloskey, 2016; Parsons, 2007; Sikkink, 1991; Widmaier, 2016), which has flourished within historical and constructivist institutionalism in particular and which has recently begun emphasizing the role of agency. Fourth, in a case study I examine early inter-governmental advisory processes which culminated in the passage of the TEA of 1962 . Using process tracing, a methodology geared at causal inference by examining sequential processes within particular historical cases (see George and Bennett, 2005; Mahoney, 2010), and employing archival material encompassing correspondence, policy memoranda, and meeting minutes of advisory groups, I illustrate the influence that Kennedy's advisers had on formulating policy which provided the foundation for liberalized trade occurring later through multilateral negotiations in the Kennedy Round of GATT. I demonstrate that advisers, most prominently the Under Secretary of State for Economic Affairs George Ball, were able to construct interests in such a way that they were able to convince Kennedy that trade liberalization was the appropriate political objective to pursue, even though the president himself initially displayed only tepid support for increased economic integration. The case study does not focus on liberalized trade in toto in form of the Kennedy Round, for example, by examining all relevant domestic stakeholders and all international negotiating partners, but rather analyzes the first step in this process: namely of how agents persuaded Kennedy to pass the TEA of 1962. A discussion follows the case study in a fifth step, which highlights the strategies Ball and others employed.

This article therefore makes two contributions - one empirical and one theoretical - to the scholarly literature. On the one hand, I offer a new perspective on the empirical case concerning the burgeoning of trade liberalization in American policy during the Kennedy administration, underscoring the importance of ideational factors in policy formulation. On the other hand, addressing the theoretical under-specification of agency in historical and constructivist institutionalist accounts, I posit that a focus on strategic action - how ideas are made actionable and how agents can induce others to adopt a particular ideational framework - can help make progress in comprehending agency better.

\section{Contextualizing the political economy of American trade policy in the early $1960 \mathrm{~s}$}

Trade policy in the Kennedy administration is a perplexing case for study because the historical circumstances made trade liberalization unlikely. As Jacob Viner's comment suggests, there was indeed little reason to assume at the beginning of the Kennedy presidency that significant liberalization would occur. Indeed, scholars have noted that the 1950s were a period in which liberalization had decelerated through an increase of restrictions, and liberal trade policy faced increased opposition in Congress and 
among the public on aggregate (Bauer et al., [1963]1972; Brusse, 1996, 1997; Coppolaro, 2013; DiLeo, 1999; Winand, 1997a). Moreover, by the time Kennedy assumed office, the conditions had not improved; quite the contrary, several of the conditions had deteriorated, casting doubt on the ability of the administration to pursue liberalizing policies (Alkema, 1999; Barnet, 1983; Diebold, 1999; DiLeo, 1999). This does not suggest that the previous administration did not pursue similar goals of increased economic integration - indeed the Eisenhower administration did - but it highlights the crucial point that at a time at which the conditions were hardly amenable to increased liberalization, the TEA of 1962 marked a significant departure from past policy. It affirms the supposition that American trade policy post-World War II was not an example of path-dependency (as asserted by Goldstein and Gulotty, 2016: 612). Indeed, a change in thinking about liberalized trade occurred.

First, American commerce faced a transformed business landscape in the 1960s. Many industries and firms no longer held the same position globally they had grown accustomed to in the early postwar era. With much of Europe and Japan in ruins following World War II, it was American firms and their industries which held competitive advantages. By the late 1950s, however, firms in other parts of the world had had a decade to recover from the war and were becoming increasingly competitive in American markets (Eckes, 1995: 157-177; Irwin, 2017: ch. 10; Paterson, 1989: 8).

Second, this phenomenon had a related effect on the organization of commercial interests and the political demands made on Washington. The 1960s experienced concerted efforts by many American industries to try to protect themselves from foreign competition. Concerned about their inability to compete with firms in Western Europe and Japan, an increasing number of American industries lobbied the American government to protect their domestic markets (Bauer et al., [1963]1972; Brusse, 1996, 1997; Coppolaro, 2013; DiLeo, 1999; Winand, 1997a). George Humphrey, Dwight Eisenhower's Secretary of the Treasury, had underscored this point as early as 1954, noting that 'we were protectionists by history and had been living under a greatly lowered schedule of tariffs in a false sense of security because the world was not in competition. That has changed now and the great wave of world competition from plants we had built for other nations was going to bring vast unemployment to our country' (cited in Eckes, 1995: 168). While trade liberalization would also have provided the prospect of greater access to foreign markets, industries and firms were generally far more concerned about protecting their domestic markets than they were about potential new markets abroad (see Borden, 1989: 76-77). In discussions among Kennedy's advisers, a self-understanding emerged which corroborated this development: 'Americans are not strong seekers of export opportunities. [The Department of] Commerce called in about 40 trade associations but heard mostly about protection, not the desire for export opportunities' (Summary Record, 1961: 2). ${ }^{1}$

Third, concern about the balance of payments played a significant role in Kennedy's presidency. In the 1950s, the United States - a traditional surplus nation - had entered a balance of payments deficit, raising concern with many policymakers. The centrality of the payments problem resulted in the creation of a working group which met regularly to tackle the issue. The group published quarterly reports both to forecast the developing problem and to seek ways to decrease the deficit. In seeking to address the problem of the deficit and the associated depletion of gold reserves, one approach was to pursue neo-Mercantilist policies. Erecting trade barriers could reduce imports, which would in turn have a favorable impact on the balance of payments. It would also have catered to calls for the protection of the domestic market. A rallying call was thus to keep foreign markets open while simultaneously protecting one's own.

Fourth, public support for trade liberalization was also waning. Prevailing reactions to the wave of trade liberalization instituted with the Trade Agreements Act of 1934 consisted of general skepticism, as was evident in decreasing public support for tariff reductions (Bauer et al., [1963]1972: 81-82). Unsurprisingly, this also led to similar perspectives becoming entrenched in Congress.

Yet many dynamics, including non-economic concerns, were in play. Advocates in favor of increasing economic integration generally cited geo-political reasons for trade liberalization. A major reason to

\footnotetext{
${ }^{1}$ On the impact of interest groups and Congressional pressures, also see Pastor (1980: 107-114).
} 
support economic integration with Western Europe and Japan consisted of maintaining a geo-political alliance against the Communist bloc. In this vein, the formation of the European Economic Community (EEC) through the Treaty of Rome in 1957 had implications for American trade policy. The United Kingdom, already a member of the European Free Trade Association, was in talks to join the EEC. Its expected accession to the Common Market by late 1961 was seen by American policymakers as a decisive marker in the evolution of the post-World War II global trading system. With the UK poised to join the trading bloc, the question arose as to how the United States would respond to being outside of it: did a customs union of which it was not a member imply a challenge to the post-war order the United States was instrumental in creating? Would an expanding EEC be 'outward-looking', or would it protect itself behind a common external tariff? And did further European integration not threaten American commercial interests?

Ambiguity about how to answer these questions revealed the incertitude - and hence policy indeterminacy - present at the time. This is, therefore, the counterfactual of the story: increased trade liberalization hardly appeared propitious in the 1950s. By the early 1960s, such factors had become even more pronounced. And yet precisely at this time a shift toward re-establishing a strikingly liberal trade policy occurred. While there was thus little reason to assume that more liberalization would ensue in the early 1960s, the Kennedy administration passed new legislation - the TEA of 1962 - enabling sweeping trade liberalization by the end of the decade.

\section{Problems with rationalist explanations for American trade liberalization in the $1960 \mathrm{~s}$}

Why did policy change come about at a period when the context of the time was everything other than amenable to trade liberalization? While there is no shortage of approaches outlining the historical developments of American trade policy in the 1960s (Eckes, 1995; Irwin, 2017: ch. 11; Zeiler, 1992), social science research has also extended to explaining the theoretical basis for trade liberalization - in other words why trade liberalization occurred in the decade. Within a rational choice framework, different academic disciplines have emphasized different theories. International relations theory popularized several approaches, including (neo-)realist (Krasner, 1976) and liberal perspectives (Keohane, 1984). Early arguments that hegemony leads to a more open trading structure suggest on the one hand that the presence of American hegemony should foster economic integration; on the other hand, in the case of the relative decline of a hegemon's national economy, contrasting policies are expected which bring about less economic integration. As Stephen Krasner (1976: 340) himself admits, however, this perspective cannot explain American trade policy in the 1960s. Liberal positions, in contrast, hold that the emergence of an international trade regime came about to overcome problems of international cooperation, thereby offering an explanation of why liberalized trade came about in the 1960s. Yet such a perspective cannot account for why in the decade preceding Kennedy's election, the process of liberalization was gradually being undone.

That there was a clear distinction between trade policy in the 1950s - with an increasing number of restrictions on liberalized trade - and the 1960s - with fewer restrictions on liberalized trade - is an important distinguishing feature for theories which purport to explain the emergence of trade liberalization. Public choice analysis offers an account for liberalization at this particular time by employing an interest group perspective. Andreas Dür (2007) suggests that lobbying by interest groups is the decisive criterion, and that exporters who fear a loss of market share abroad lobby their governments more against potential losses of market share than they do for potential gains in foreign markets. Applying this principle to American trade policy in the 1950s and 1960s, Dür suggests that there was little concern by American exporters that they could lose market share abroad in the 1950s, which explains the absence of intense lobbying by American firms to seek expanded trade liberalization. It was during this timeframe that 'the process of liberalization not only stagnated but, if anything, was on the verge of reversal' (ibid.: 460). In contrast, the formation of the European Economic Community's (EEC) Common Market had an impact on American firms in the late 1950s and early 1960s as they feared losing market share, leading them to lobby in favor of increased market 
access abroad. Dür (ibid.: 467-468, 473-474) points to Congressional testimony by exporting interest groups to illustrate his point. ${ }^{2}$

While this account offers a compelling logic of liberalization, the empirical evidence he cites occurred long after the decision had already been made by the Kennedy administration to make the TEA of 1962 a legislative priority. Administration officials' lament concerning the restraint by American industry to demand market access abroad - moreover, their calls for protectionism casts further doubt that business interests proved to be the decisive factor in pushing for increasingly liberal trade policies. ${ }^{3}$ Economic structure did not predict policy, and the politico-economic changes occurring during this time period had to be interpreted by agents - what constituted rational action was itself not self-evident; it was indeterminate. Its merit of analytical rigor notwithstanding, the challenge for a rational choice perspective consists of acknowledging that its theoretical approach, especially in the face of policy indeterminacy, does not account for the beliefs upon which interpretation rests. Moreover, these beliefs are not exogenous (Bates et al., 1998: 635). This implies that ideas become important to consider how individuals' values and their goals are constructed.

\section{The role of ideas, historical and constructivist institutionalism, and a conception of agency}

In contrast to approaches which see decision-making by agents determined by their societal positioning and their adoption of structurally immanent interests, reference to historical (HI) and constructivist (CI) institutionalism and their focus on the importance of ideational factors (Blyth, 2002; Campbell, 1998; Hall and Taylor, 1996; Morrison, 2012, 2016; Woods, 1995) provides theoretical structures through which to make sense of the policy changes described above. ${ }^{4}$ Recent accounts of endogenous change in this literature have emphasized the interplay of ideas and interests and how the former shapes the latter; in contrast to rationalist approaches, it is thereby assumed that 'interests' do not merely exist, but rather that they are constructed (Blyth, 1997, 2003; Campbell, 2002; Hay, 2006, 2011; Lieberman, 2002; Schmidt, 2008; Woods, 1995). This implies that cognition is important in that individual agents interpret their surroundings in their own idiosyncratic ways and thereby derive their own principal cause of motion for action - indeed, societal 'structure itself says nothing about how specific individuals perceive and react to their circumstances. From military to monetary intervention, men and women still make their own history' (Morrison, 2016: 203, emphasis added).

The traditional conception within sticky versions of HI was to consider individual agency predominantly through a structuralist lens: when analyzing the factors leading to institutional change, the scope of investigation had been to examine the institutional arrangements of change; agents themselves frequently only played subordinate roles in explanations (see Capoccia and Kelemen, 2007; Hall, 1989; Mukherji, 2013; Slater and Simmons, 2010; Soifer, 2012; Weir, 1989). The tendency has been corrected in part of late in accounts employing more constructivist approaches to the study of institutional change, where there have been calls insisting on the import of agency into HI in a more pronounced fashion (see Blyth, 2007; Hall, 2016; Hay and Wincott, 1998; Widmaier et al., 2007; Blyth, 2016). Calls for an 'agent-centred historical institutionalism' (Bell, 2011: 890) mark a significant - albeit not a widespread - shift in contrast to traditional perspectives. ${ }^{5}$ To make theoretical progress implies 'inject[ing] agency into institutional accounts, but in a way that generates portable propositioning to identify broader patterns' (Conran and Thelen, 2016: 64, emphasis in original). Agency should no longer be viewed as a black box, and too little is understood of what is going on

\footnotetext{
${ }^{2}$ For a critical perspective of Dür's empirical account, highlighting the wealth of archival material which was not considered, see Huempfer (2016: 42).

${ }^{3} \mathrm{An}$ advisory group of economic consultants maintained that on the whole 'US industry has resisted liberalization' (Summary Record, 1961: 2-3).

${ }^{4}$ There is a debate (Bell, 2011; Schmidt 2011) whether CI should be viewed as separate from HI, or whether constructivist perspectives can be subsumed under HI. The point is not to insist on classificatory distinctions; rather, it is about highlighting that there are distinct approaches with some emphasizing institutional stickiness and others institutional discontinuity.

${ }^{5}$ For the only specification of agency in the field to date, see Bell (2017).
} 
under the hood. It is particularly important especially because much research favorably disposed to incorporating agency into the study of institutional change does not concern itself with actors themselves, but rather displays a pre-occupation with the structural conditions that allow agency to surface in the first place (Capoccia, 2016; Capoccia and Kelemen, 2007; Mahoney and Thelen, 2010; Mukherji, 2013).

In spite of endeavoring to make theoretical progress, historical case studies can be particularly fruitful in this regard. If researchers allege to take historical specificity seriously, it implies the recognition of a view which places agents in the midst of real situations - i.e. situated agency - and invites scholars to consider institutional constraints and the manner through which actors may circumvent, muddle through, or even make use of obstacles they encounter. Agents may face difficulties or hurdles in the objectives they are hoping to effect, but this does not imply that they react in a defeated way to the conditions as they exist; they may seek to change them. Theoretically this implies that while agency is about action, it is thus simultaneously - given the ideational focus in both HI and CI - also about making ideas actionable. ${ }^{6}$ And how ideas are made actionable reveals how actors behave strategically. This itself can serve as a way through which we may understand agency better. Employing ideas in concrete political settings with the goal of making them actionable can undoubtedly occur in countless ways, because agents make use of a panoply of forms of strategic action to achieve their goals, making agency an open concept. But it is hereby - by tracing such strategic action - that the ideational component can become an inextricable component of agency in the ideas and institutions literature, adding substantive content to the hitherto ill-defined black box. This view therefore affirms the supposition and adopts the perspective that institutions are not merely (or even primarily) behaviorstructuring phenomena; rather, they are 'instruments in the hands of actors' (Blyth et al., 2016: 158). The instruments themselves become 'the subject and focus of political struggle' (Hay, 2011: 68) through the strategic action carried out by agents. ${ }^{7}$

Applying this concept to the Kennedy administration is instructive. Political objectives - i.e. what constituted the national interest - were constructed, and the ideas and strategic action of one leading adviser (and his associates) were instrumental in convincing Kennedy to pursue an economically more closely integrated (Western) world with fewer economic restrictions in spite of present constraints. In so doing, 'the tide [that was] running in a protectionist direction' (Viner, 1961: 565) was overcome.

\section{Kennedy's advisers and their influence on the formulation of trade policy}

Kennedy himself was anything but 'a doctrinaire free trader' (Borden, 1989: 64). ${ }^{8}$ As a senator from Massachusetts, he was exposed to the demands of special interests, voting, for example, against lower textile tariffs in 1949 (Ball, 1982: 188-193). Indeed, after winning the 1960 election, it was not entirely clear what kind of foreign economic policy he would pursue. Commitments from the campaign trail revealed little support for economic integration. Seeking to win the support of states in New England and the American South with an industrial base in textiles, Kennedy had given assurances to the industry, promising to resolve their 'import problem' (ibid.: 188). An aide at the time later described the situation in the following terms: 'There was nothing crystal-clear in President Kennedy's record on trade policy. New England was not a natural home for trade liberalization, and his congressional record on these matters had been a bit spotty' (Diebold, 1999: 239). On the question of European integration, one historian notes that '[a]t best [Kennedy] was a skeptic' (Winand, 1997b: 139).

\subsection{Proposing trade liberalization: George Ball approaches Kennedy}

A chief influence on Kennedy's views on foreign economic policy and the formulation of the TEA of 1962 occurred through his advisers. None were as persuasive as George Ball, who worked actively to

\footnotetext{
${ }^{6}$ On filling institutions with ideational content, see Dabrowska and Zweynert (2015).

${ }^{7}$ As a parallel to this point, see the emphasis on the importance of agent-sensitive institutions (cf. Hodgson, 2006: 16-17).

${ }^{8}$ See also Preeg (1970: 45), Alkema (1999) and Diebold (1999) who question Kennedy's principled commitment to liberalized trade.
} 
influence foreign economic policy of the administration and who would be named Under Secretary of State for Economic Affairs in the State Department. Although not an economist Ball was a consummate free-trader, developing his views on the matter and his preference for economic integration over the preceding decades. He noted that 'according to classical doctrine, each country should concentrate on that type of production in which it has some comparative advantage' (Ball, 1982: 187). ${ }^{9}$ Yet his preference for integrated economies extended beyond textbook considerations of economic welfare. Ball drew dual historical lessons from the 1930s: the absence of economic cooperation, he believed, had led to conflict in Europe and precluded the United States from countering the rise of Nazism earlier. He writes in his autobiography:

I felt it essential that we rid the world economy of its encrusted barnacles of trade and monetary restrictions. [...] Our mindless protectionism of the late twenties and early thirties had helped to precipitate the world's economic collapse and to create the conditions that fostered the rise of Hitler - at the same time that our isolationism (the other face of protectionism) had induced us to stand numbly by while the world slid to catastrophic war (ibid.: 103).

Having supported Adlai Stevenson in his campaigns for the presidency in 1952, 1956, and 1960, Ball approached Stevenson about ways to have an influence on the Kennedy administration after Kennedy had secured his party's nomination for the presidency. While the platform for the Democratic Party in 1960 had included urgent language about the need for liberal trade, this, at times, provided certain tensions with Kennedy's own views, which can best be summed up as a fair-trade doctrine (Zeiler, 1992: 36-46). ${ }^{10}$ Stevenson, at Ball's behest, sought to prod along Kennedy to focus less on reciprocal trade, but rather to pursue liberal trade. Known as the 'Stevenson Report', for which, however, Ball was predominantly responsible as author, it provided the recommendation of a policy program for the new administration. Kennedy's approval of the report led to the assignment of a task force on foreign economic policy, which was headed by Ball and focused on issues such as the balance of payments, trade policy, international economic development, and the OECD (Bill, 1997; Task Force on FEP Report, 1960). The task force outlined specific recommendations for action, spelling out in much greater detail what an integrated foreign economic policy program could look like and what it should aim to accomplish. At the center of the report was the idea to argue for the necessity of a commercial policy overhaul. Suggesting that new tools were needed to address a changing world, the report read that ' $[\mathrm{i}] \mathrm{n}$ the last decade, conditions have materially changed but our policies have not been revised to reflect the following changed circumstances of Free World relationships' (Task Force on FEP Report, 1960: 8). To this end, significant changes to trade policy were sought to allow for across-the-board tariff reductions (as opposed to product-specific reductions); to revise peril point and escape clause provisions which could significantly undermine liberalized trade; and to provide adjustment assistance to displaced labor and industry temporarily, replacing the 'no serious injury' principle (ibid.: R-3; Memorandum by Petersen, 1961b).

Through his position in the State Department, Ball would lead efforts to liberalize trade policy along with advisers from both the White House and other cabinet departments. He did not act alone, nor was he the only official in the Kennedy administration to argue forcefully for trade liberalization. Howard Petersen, a Republican banker, was appointed Special Assistant to the President for International Trade Policy tasked with the advancing liberalization efforts from the White House. The Secretary of Commerce, Luther Hodges, sympathetic to the proposed policy, was chosen to push the

\footnotetext{
${ }^{9}$ That Ball's convictions were also present in practice is evident through his self-portrayal in negotiations with business groups on trade issues. He writes: 'For my private and secret gratification, I appeared before each textile group [with which we conducted negotiations on the legislation we proposed] dressed in a British-made suit, a British-made shirt, shoes made for me in Hong Kong, and a French necktie...As I was leaving one meeting, I heard an industry representative say, "That's the slyest bastard I've seen in years. We certainly have to watch him." I found such praise heart-warming' (Ball, 1982: 190-191).

${ }^{10}$ I thank an anonymous reviewer for pointing out the language of the Democratic Party platform.
} 
trade agenda through Congress because of his connections to industrialists who could have viewed the removal of trade restrictions unfavorably. In short, there were several actors who played a role in contributing to the construction of interests.

Nevertheless, Ball was undoubtedly the most influential figure and therefore a focal point. Arguing forcefully on the matter of trade, he also chaired an inter-departmental committee which was formed in the summer of 1961 and served as a basis to establish the path forward. Members of the Ball Committee were well-aware of the difficulty of the challenge to effect more liberal trade policy. In a memorandum to Kennedy, Petersen noted the 'hostility to liberalization' which existed with the general public (Memorandum by Petersen, 1961a: 1). This perspective was also attributed to American industry, which, to the frustration of the Committee members, had 'resisted liberalization' because 'Americans [are] not strong seekers of export opportunities' (Summary Record, 1961: 2). Threats of competition in labor-intensive products by lesser developed countries were perceived as 'the most terrifying thing'. Indeed, Ball noted 'a spirit of defeatism in business circles' which he found deeply disturbing (ibid.: 1-2).

The sentiment was also shared about beliefs on Capitol Hill, namely that 'protectionism in Congress is stronger today than ever' (Summary Minutes, 1961c: 6). Members of the Committee realized that they must be tread carefully, understanding that there were 'continued pressures for protectionism... [which could entail] retaliatory action in our approach to emerging problems' (Memorandum from Treasury Department, 1961: 9). The point to be made here is that officials advising Kennedy themselves believed that they were propagating deeply unpopular policies, and they faced little illusion of the difficulty of their self-appointed task. This by itself does not prove that ideational factors were their impetus for action, but their alignment with unpopular political stances suggests at the very least that they did not seek out the advancement of politically opportune positions.

\subsection{The UK's expected accession to the EEC and the balance of payments problem}

Two political issues grant insight into how interest construction proceeded and how advisers were able to employ such issues to further their policy objectives. First, the issue of whether the United Kingdom would accede to the EEC was key in the early 1960s. It was an open question whether the United States would support the UK bid. Growth of the EEC could have adverse economic effects for American industry resulting from trade diversion, and it was unclear whether trading preferences might also be extended to Commonwealth countries in future EEC negotiations, inducing further discrimination to American products. ${ }^{11}$ Indeed, Kennedy shared this apprehension, noting in a memorandum: 'I am concerned about what will be the economic effect upon the United States if England joins the common market...I have been informed that the effect will be extremely serious...If it should have an extremely adverse effect upon us a good deal of responsibility would be laid upon our doorstep' (Kennedy to Ball, 1961). In responding, Ball stressed that the United States had supported European integration since the Marshall Plan, and that it should continue to do so in line with its foreign policy objectives. However, considering the developing structural economic changes, much greater attention was paid to economic benefits the United States could reap. He replied to Kennedy that the UK joining the EEC 'would suggest that the net effect of British adherence to the Common Market should be favorable to our industrial trade' (Memorandum by Ball, 1961c: 3, emphasis in original). It was argued, in other words, that trade creation - expected due to growing demand for American products from Common Market growth - would outweigh trade diversion brought about by the UK's closer economic alignment with the EEC.

That this alleged outcome of an improvement of American trade would occur through the move of an important export market into a trading bloc with a common external tariff applying to the United

\footnotetext{
${ }^{11}$ The open-ended nature of what American policy toward UK accession to the EEC would be does not suggest that support or lack thereof was systemically immanent, but rather that this was an indeterminate process in which perceptions of what constituted 'American interests' were carefully negotiated. See Winand (1997a: 176) and Coppolaro (2013: 30-31) on American uncertainty concerning British accession.
} 
States suggests spurious reasoning. Indeed, it was also not believed by Kennedy's advisers. In a memorandum summarizing the meeting of the Ball Committee on September 6, 1961, Kermit Gordon, a permanent member of the Committee and a member of the Council of Economic Advisers, reported that:

I suggested, referring to the State Department's estimate of the decline in U.S. exports to Western Europe which could be attributed to the full coming into being of the common market, that it might be possible to estimate the amount of the tariff reduction which would be necessary to compensate for this effect (Gordon to Heller and Tobin, 1961: 1, emphasis added).

Clearly, contrary to the optimistic outlook Ball presented to Kennedy, there was an acknowledgment (and a State Department report) that the UK's accession to the Common Market would actually hurt American economic interests. ${ }^{12}$ This was simply neglected in communication with Kennedy. Rather, the Ball Committee utilized an approach in which they stressed the advantages for American trade of an expanding EEC, and secondarily - as an afterthought - pushed for the lowering of restrictions of the Common Market's external tariff 'at the appropriate time' (Summary Minutes of FEP, 1961a: 3). By stressing alleged economic advantages to Kennedy, support for expanded economic integration objectives the advisers advocated - was to be effected.

Second, a similar approach is evident in terms of how advisers handled the balance of payments dilemma. With the United States beginning to run a payments deficit in the 1950s, it had an obvious impact on the formulation of new trade policy. ${ }^{13}$ Faster growth of exports over imports would have a positive impact on payments, while the opposite would worsen the deficit. A meeting of the Ball Committee addressed this issue, acknowledging that greater disposable income associated with the expected domestic recovery following the recession in the United States would make matters worse, since imports would increase (Summary Minutes, 1961b: 3). It presented a real challenge for the advisers because while greater export opportunities could have mitigated the payments deficit, trade liberalization did no such thing per se. Indeed, among the Ball Committee members there was an understanding that there was 'even a semi-respectable argument for protectionism - the balance-of-payments deficit' (Summary Minutes, 1961c: 6).

Yet pursuing a neo-Mercantilist foreign economic policy was anathema to Ball and other presidential advisers, which became evident in Ball's criticism of Kennedy's justification of protectionist measures to address the balance of payments problem (Memorandum by Ball, 1961a). And so they sought to undermine any possible arguments in favor of trade restrictions in their dealings on the matter with Kennedy. Indeed, it was common practice, such as in a memorandum from the Treasury Department, to argue only one side of the payments issue, highlighting the need to push exports to alleviate the deficit. Moreover, much as the anticipated economic impact of the UK joining the Common Market was not communicated forthrightly to Kennedy, so too did Ball simply assert that it is likely that the increase in imports attributable to the new tariff authority will be relatively small' (SC to Ball, 1961: 8).

Stressing liberalized trade as a response to both the anticipated growth of the Common Market and the payments problem had an impact on Kennedy, as he internalized a trade program as a viable

\footnotetext{
${ }^{12}$ Separate memoranda, such as one projecting the harm American agricultural interests would encounter if the UK joined the Common Market, were present at the time. See Memorandum by Cooper (1961: 2).

${ }^{13}$ Throughout his presidency, Kennedy was particularly 'obsessed' with the issue, as Ball notes in his autobiography: the 'brooding concern with the problem of our depleting gold reserves reflected the influence of his father, Joseph P. Kennedy. As a brilliant speculator and market manipulator, the elder Kennedy was obsessively conservative with regard to public finance; to him our gold resources were a significant measure of our national strength and authority. [...] So, whenever the President returned from Hyannis Port, we braced ourselves for a sermon on gold and the hellfire awaiting us if we did not promptly correct the balance of payments deficit' (1982: 205). Costigliola (1989: 30) underscores this point, describing the two dangers that scared Kennedy most as being nuclear war and the balance of payments deficit.
} 
response. This is evident, in particular, in the meeting notes of a discussion on foreign trade policy with senior advisers:

Regarding the relationship of the trade program to our balance of payments, it was mentioned that if Congress failed to pass the new trade program, the Common Market external tariff would remain at present levels and we would stand to lose at least part of our current export sales to Europe which would be able to continue selling to us as before - thus further impairing our balance of payments. The President's rejoinder was that this was not necessarily so, that we could, for example, raise our own tariffs if necessary. This possibility was only mentioned in passing and was not discussed. The President did, however, reiterate his deep concern about the outflow of gold and our overall balance of payments problem and said that the new trade program must be presented as means of assuring full access to the Common Market for U.S. exports and as an alternative to the possible need for some form of restriction on U.S. overseas investment (Summary Minutes of Discussion on Foreign Trade Policy, 1961: 3-4).

That Kennedy was willing to propose retaliatory tariffs as a response to potentially failed efforts to formulate an agreement with the EEC only underscores his loose commitment to liberal trade policy. Yet simultaneously viewing the proposed trade program as the solution to problems the administration faced reveals that liberalized trade was successfully formulated as constituting the national interest.

\section{Analysis and discussion}

How did this process of interest construction come about? Ball and his associates employed several strategies to shape the national interest in such a manner so that liberalized trade and increased economic integration were viewed as appropriate public policy objectives. First, the changed nature of world trade was emphasized as necessitating action (Task Force on FEP Report, 1960: X). Second, grandiose language was employed by Kennedy's advisers to frame the political economy of trade. The trade authority Kennedy had inherited with his assumption to office was described as 'bankrupt' (ibid.: 24), as 'grossly inadequate' (SC to Ball, 1961: 1), and as being 'at a dead end' (Memorandum, anon., 1961: 1). Third, much like the administration framed the issue to the general public by placing 'the accent on the new opportunities, not the dangers' (Summary Record, 1961: 1), Kennedy's advisers employed the same strategy in their discussions with the President. They were careful to communicate those messages which would lead to support of their policy objectives and withheld information which could have jeopardized their goals. Fourth, contextualizing proposed actions toward deeper economic integration as congruent with the overarching spirit of long-held policy dicta - when the policy objectives Kennedy's advisers sought represented a significant departure from the policy of the preceding years - also offered a sense of traditional continuity. As one adviser noted, the conditions which had given rise to the Marshall Plan were essentially gone (DiLeo, 1999: 263). Fifth, advisers like Ball stressed the combative nature of interest groups, positioning the administration as defending American interests. 'We can count on the protectionists', Ball noted, 'doing everything possible to tie your hands and to try to force the United States to take positions in the European negotiations that run counter to our long-range interests, both political and economic' (Memorandum by Ball, 1961d: 3).

The policy goals pursued by the Kennedy administration were no fluke; they were neither structurally pre-determined, nor were they immanent to the trade system of the early 1960s. Indeed, policy indeterminacy reigned. Kennedy's advisers were able to construct interests and shape beliefs in such a way that trade objectives were endogenized: Kennedy himself came to embrace trade liberalization as an expedient tool and a policy goal to be pursued. Moreover, shaping matters in such a way that Kennedy came to understand the national interest as entailing steps toward trade liberalization reveals that the strategic action Ball and others employed was carried out intentionally. It was not the case that his advisers were simply responding to external circumstances. 
Borrowing from approaches which highlight how agents may make use of knowledge asymmetries and uncertainty to pursue their material interests (Niskanen, [1971] 2007), one can detect how Ball and others made use of their deep involvement in the intricacies of trade questions in the early 1960s to present the President with information favorable to their cause, omit reports that would have raised doubts about the suitability of the policy they hoped to effect, and provide an overall picture that was amenable to the goals they sought. It is possible to extend this logic to highlight that Kennedy's advisers were able to exploit knowledge asymmetries to control what and how they communicated with the President to further their own ideational - not structurally immanent - interests.

The description of how advisers were able to convince Kennedy to pursue liberal trade is not meant to suggest that they were omnipotent in translating their ideas into practice. Indeed, the mere existence of ideational convictions says little about the success of furthering ideas within public policy. After all, it is generally the case that there are competing policies - and competing ideas - at disposal for political action. Ball, for example, strongly believed in mandating the OECD with greater responsibility in managing global commerce, noting that the organization was best suited to addressing 'real economic problems' (Memorandum by Ball, 1961b: 9). Yet this would have implied a significant transfer of decision-making authority, institutional change which did not garner sufficient support. That Ball was unsuccessful in this respect highlights that actors do find themselves in settings with potent institutional constraints; presenting actors as invincible figures whose agential limits know no bounds fails to appreciate the exigencies of their political realities. Ball and 'the Europeanists' were not able to bring about everything which they thought constituted good policy. There were also setbacks they encountered: most notably, the Short-Term Arrangement on cotton textiles, a largely protectionist agreement setting export quotas, was concluded in July 1961, which was viewed as necessary by Kennedy to assuage an important industrial group (Irwin, 2017: 524; Pastor, 1980: 109; Preeg, 1970: 52-53). It also sheds light onto the assessment that while the conclusion of the Kennedy Round saw a new wave of trade liberalization, it was not the case that the 1960s were free from protectionist elements becoming entrenched.

Agents' success will depend largely on the unique situations within which they find themselves at the beginning of their strategic action, the methods and strategies they employ in advancing their ideational convictions, and the exigencies of both their particular circumstances and those of the overall political system within which they are operating. It might not be surprising that political advisers acting in the background were particularly influential on a question that is typically considered to be an 'expert issue' - such as trade policy - which is generally developed and negotiated by technocrats behind closed doors.

Taking seriously what individual agents believe and how they act stands in contrast to functionalist perspectives in which individual agents merely follow pre-determined logics. This, too, can be a problem with rationalist accounts if, in seeking to explain the mechanisms of change, they rely presumptuously on the logic of choice without considering how values, preferences and interests - that which agents seek to achieve - are constructed. It is suggested thereby that if there is a comprehensible logic to the way agents operate - typically assumed as rational, utility-maximizing behavior - that one need not look any further and that the explanation for the given historical case is thereby determined. In this view, interests agents have are exogenous; they are assumed, not explained. To be clear, I do not wish to claim that rationalist approaches have no merit. They excel particularly through their analytical rigor in stable institutional settings. The point is, however, that they do not and cannot account for 'the struggle over subjective worldviews [which] should itself be treated as a strategic process' (Bates et al., 1998: 634). ${ }^{14}$ In this case, paying heed to the strategic action carried out by agents - in other words by taking agency seriously - is essential to understanding institutional change in American trade policy.

\footnotetext{
${ }^{14}$ This does not suggest, however, that there are only either-or approaches. Indeed, perspectives can be complementary, and rationalist frameworks can be supplemented by accounts which examine how interests are constructed.
} 


\section{Conclusion}

This article has made one empirical and one theoretical contribution. Empirically, I demonstrate that rationalist accounts overlook important motivations for trade liberalization initiated in the Kennedy administration. The trajectory of trade policy was indeterminate at the time of Kennedy's assumption to office, and the specific formulation of trade policy was dependent on factors which cannot be accounted for by rationalist perspectives alone. Kennedy's advisers, most notably Under Secretary of State George Ball, were instrumental in shaping policy in the early 1960s. Ball and others constructed the national interest for Kennedy in such a manner that it was considered to include trade liberalization. Especially the 'contradictory' information presented by Ball and other actors on the impact of the UK's accession as well as their decision not to communicate import restrictions as a viable solution to address the payments issue underscores the nature of strategic action carried out by Kennedy's political advisers. This strategic action suggests that Ball and others argued adamantly in favor of trade liberalization because of their ideational commitments pertaining to liberalized trade. Convincing Kennedy only constituted a first step. Neither had this guaranteed public support, nor was progress established in moving legislation through Congress or negotiating multilateral trade agreements, which occurred through the TEA of 1962 and the Kennedy Round of GATT. Even so, this case study is important as there would have been no Kennedy Round without Kennedy.

Theoretically, the specification of agency as strategic action wherein ideas are made actionable contributes to the literature on endogenous change in institutionalist accounts by making a proposition of an agency-centered approach, thus taking a small step in overcoming the vacuity that most conceptions have exhibited to date. The account proposed here of agents making ideas actionable invites scholars to consider agency in these terms - what do they believe and how do they act to further their own objectives? Especially in light of the deficiency of agency under-specification in many institutionalist approaches, this concept promises to provide one step forward in developing 'portable positioning to identify broader patterns' (Conran and Thelen, 2016: 64, emphasis in original) in tracing institutional change. In so doing, it may thus be high time to shift the current balance and provide agential conceptions of institutional change a more prominent place in the field than they currently inhabit.

Acknowledgements. The author gratefully acknowledges helpful comments from Joachim Zweynert, Deirdre McCloskey, Stephen Meardon, Nils Goldschmidt and Laura Otto. This manuscript has also improved through the valuable feedback by participants of the History of Economics Conference at Loyola University (June 2018), the Center for the History of Political Economy's Summer Institute at Duke University (June 2018), the History of Recent Economics Conference at Université de Cergy-Pontoise (October 2018), and the Chicago-Siegen Kreis (December 2020). Special thanks for their tireless work are extended to the reference librarians at the John F. Kennedy Presidential Library and the Seeley G. Mudd Library at Princeton University, where archival research was conducted. The usual caveat applies.

\section{References}

Gordon to Heller and Tobin, 7 September 1961, Kermit Gordon Papers, Box 32, Foreign Economic Policy, Folder 3. John F. Kennedy Presidential Library and Museum.

Kennedy to George Ball, 21 August 1961, George W. Ball Papers, Box 103, Folder 1 Chron Files, 1961 Jan-Aug. Seeley G. Mudd Manuscript Library, Princeton University.

Memorandum by Dick Cooper, 'Meeting in Tyler's Office on Accession of the United Kingdom to the Common Market', 11 September 1961, Kermit Gordon Papers, Box 32, Foreign Economic Policy, Folder 3. John F. Kennedy Presidential Library and Museum.

Memorandum by George W. Ball, 'Memorandum for the President', 23 October 1961d, Howard Petersen Papers, Box 2, Trade Legislation \& Correspondence on Proposals [1/13/61-11/5/61] Folder. John F. Kennedy Presidential Library and Museum.

Memorandum by George W. Ball, 'Proposed Position of US Regarding Macmillan Statement on UK-EEC Negotiations', 3 August 1961b, George W. Ball Papers, Box 103, Folder 1 Chron Files, 1961 Jan-Aug. Seeley G. Mudd Manuscript Library, Princeton University.

Memorandum by George W. Ball, 'U.K. Adherence to the European Common Market', 23 August 1961c, Kermit Gordon Papers, Box 32, Foreign Economic Policy, Folder 3. John F. Kennedy Presidential Library and Museum.

Memorandum by George W. Ball, 29 March 1961a, George W. Ball Papers, Box 103, Folder 1 Chron Files, 1961 Jan-Aug. Seeley G. Mudd Manuscript Library, Princeton University. 
Memorandum by Howard Petersen, 'Plans for Development of Foreign Trade Program', 12 September 1961a, Howard Petersen Papers, Box 2, Trade Policy Memorandum of [10/4/61] Correspondence on Proposals Folder. John F. Kennedy Presidential Library and Museum.

Memorandum by Howard Petersen, 'Proposals for 1962 United States Foreign Trade and Tariff Legislation', 4 October 1961b, Kermit Gordon Papers, Box 32, Foreign Economic Policy, Folder 1. John F. Kennedy Presidential Library and Museum.

Memorandum, anon., '1962 Trade Agreements Legislation: Background', 12 October 1961, Kermit Gordon Papers, Box 32, Foreign Economic Policy, Folder 3. John F. Kennedy Presidential Library and Museum.

Memorandum from Treasury Department, 'The Balance of Payments and Our Foreign Economic Policy', 1961, Kermit Gordon Papers, Box 32, Foreign Economic Policy, Folder 1. John F. Kennedy Presidential Library and Museum.

SC to George W. Ball, 11 August 1961, Howard Petersen Papers, Box 2, Trade Legislation \& Correspondence on Proposals [1/13/61-11/5/61] Folder. John F. Kennedy Presidential Library and Museum.

Summary Minutes of Discussion on Foreign Trade Policy, 'Summary of Discussion of Foreign Trade Policy with the President at Hyanis Port on Friday, November 24, 1961', 24 November 1961, Howard Petersen Papers, Box 2, Trade Legislation \& Correspondence on Proposals [11/13/61-12/20/61] Folder. John F. Kennedy Presidential Library and Museum.

Summary Minutes of Meeting of Interdepartmental Committee on Foreign Economic Policy, 6 September 1961a, Kermit Gordon Papers, Box 32, Foreign Economic Policy, Folder 3. John F. Kennedy Presidential Library and Museum.

Summary Minutes of Meeting of Interdepartmental Committee on Foreign Economic Policy, 4 October 1961b, Kermit Gordon Papers, Box 32, Foreign Economic Policy, Folder 3. John F. Kennedy Presidential Library and Museum.

Summary Minutes of Meeting of Interdepartmental Committee on Foreign Economic Policy, 18 October 1961c, Kermit Gordon Papers, Box 32, Foreign Economic Policy, Folder 3. John F. Kennedy Presidential Library and Museum.

Summary Record of Meeting of Economic Consultants, 'U.S. Trade Policy and Trade Agreements Act', 3 October 1961 (Afternoon Session), Kermit Gordon Papers, Box 32, Foreign Economic Policy, Folder 3. John F. Kennedy Presidential Library and Museum.

Task Force on Foreign Economic Policy (FEP), 'Report to the Honorable John F. Kennedy', 31 December 1960, The Papers of President Kennedy, Pre-Presidential Papers, Box 1073, Economy - Task Force Report on Foreign Economic Policy Folder. John F. Kennedy Presidential Library and Museum.

Alkema, Y. (1999), 'European-American Trade Policies, 1961-1963', in D. Brinkley and R. Griffiths (eds), John F. Kennedy and Europe, Baton Rouge: LSU Press, pp. 212-234.

Alston, L. (2017), 'Beyond Institutions: Beliefs and Leadership', The Journal of Economic History, 77(2): 353-372.

Ball, G. (1982), The Past Has Another Pattern: Memoirs, New York: W.W. Norton \& Company.

Barnet, R. (1983), The Alliance: America, Europe, Japan, Makers of the Postwar World, New York: Simon and Schuster.

Bates, R. H., R. J. P. Figueiredo Jr. and B. Weingast (1998), 'The Politics of Interpretation: Rationality, Culture, and Transition', Politics \& Society 26(4): 603-642.

Bauer, R., I. De Sola Pool and L. A. Dexter ([1963]1972), American Business and Public Policy: The Politics of Foreign Trade, Chicago: Aldine Atherton.

Béland, D. and R. H. Cox (2016), 'Ideas as Coalition Magnets: Coalition Building, Policy Entrepreneurs, and Power Relations', Journal of European Public Policy, 23(3): 428-445.

Bell, S. (2011), 'Do We Really Need a New “Constructivist Institutionalism” to Explain Institutional Change?', British Journal of Political Science, 41(4): 883-906.

Bell, S. (2017), 'Historical Institutionalism and New Dimensions of Agency: Bankers, Institutions and the 2008 Financial Crisis', Political Studies, 65(3): 724-739.

Berman, S. (1998), The Social Democratic Moment: Ideas and Politics in the Making of Interwar Europe, Cambridge: HUP. Bill, J. (1997), George Ball: Behind the Scenes in U.S. Foreign Policy, New Haven and London: YUP.

Blyth, M. (1997), “'Any More Bright Ideas?” The Ideational Turn of Comparative Political Economy', Comparative Politics, 29(2): 229-250.

Blyth, M. (2002), Great Transformations: Economic Ideas and Institutional Change in the 20th Century, New York: CUP.

Blyth, M. (2003), 'Structures Do Not Come with an Instruction Sheet: Interests, Ideas, and Progress in Political Science', Perspectives on Politics, 1(4): 695-706.

Blyth, M. (2007), 'Powering, Puzzling, or Persuading? The Mechanisms of Building Institutional Orders', International Studies Quarterly, 51(4): 761-777.

Blyth, M. (2016), 'The New Ideas Scholarship in the Mirror of Historical Institutionalism: A Case of Old Whines in New Bottles?', European Journal of Public Policy, 23(3): 464-471.

Blyth, M., O. Helgadottír and W. Kring (2016), 'Ideas and Historical Institutionalism', in O. Fioretos, T. Faletti and A. Sheingate (eds), The Oxford Handbook of Historical Institutionalism, New York: OUP, pp. 142-162.

Borden, W. S. (1989), 'Defending Hegemony: American Foreign Economic Policy', in T. Paterson (ed.), Kennedy's Quest for Victory: American Foreign Policy 1961-1963, New York: OUP, pp. 57-85.

Brusse, W. A. (1996), 'The Americans, GATT, and European Integration, 1947-1957: A Decade of Dilemma', in F. Heller and J. Gillingham (eds), The United States and the Integration of Europe: Legacies of the Postwar Era, New York: St. Martin's Press, pp. 221-249. 
Brusse, W. (1997), Tariffs, Trade and European Integration, 1947-1957, New York: St. Martin's Press.

Campbell, J. (1998), 'Institutional Analysis and the Role of Ideas in Political Economy', Theory and Society, 27(3): 377-409.

Campbell, J. (2002), 'Ideas, Politics, and Public Policy', Annual Review of Sociology, 28(1): 21-38.

Capoccia, G. (2016), 'Critical Junctures', in O. Fioretos, T. Faletti and A. Sheingate (eds), The Oxford Handbook of Historical Institutionalism, Oxford: OUP, pp. 89-106.

Capoccia, G. and D. Kelemen (2007), 'The Study of Critical Junctures: Theory, Narrative, and Counterfactuals in Historical Institutionalism', World Politics, 59(3): 341-369.

Carstensen, M. (2011), 'Paradigm Man vs. the Bricoleur: Bricolage as an Alternative Vision of Agency in Ideational Change', European Political Science Review, 3(1): 147-167.

Conran, J and K. Thelen (2016), 'Institutional Change', in O. Fioretos, T. Faletti and A. Sheingate (eds), The Oxford Handbook of Historical Institutionalism, New York: OUP, pp. 51-70.

Coppolaro, L. (2013), The Making of a World Trading Power: The European Economic Community in the GATT Kennedy Round Negotiations (1963-1967), Farnham and Burlington: Ashgate.

Costigliola, F. (1989), 'The Pursuit of Atlantic Community: Nuclear Arms, Dollars, and Berlin', in T. Paterson (ed.), Kennedy's Quest for Victory: American Foreign Policy 1961-1963, New York: OUP, pp. 24-56.

Couyoumdjian, J. P. and C. Larroulet (2018), 'Ideas, Leaders, and Institutions in 19th Century Chile', Journal of Institutional Economics, 14(5): 925-947.

Dabrowska, E. and J. Zweynert (2015), 'Economic Ideas and Institutional Change: The Case of the Russian Stabilisation Fund', New Political Economy, 20(4): 518-544.

Diebold Jr., W. (1999), 'A Watershed with Some Dry Sides: The Trade Expansion Act of 1962', in D. Brinkley and R. Griffiths (ed.), John F. Kennedy and Europe, Baton Rouge: Louisiana State University Press, pp. 235-260.

DiLeo, D. L. (1999), 'George Ball and the Europeanists in the State Department, 1961-1963', in D. Brinkley and R. Griffiths (ed.), John F. Kennedy and Europe, Baton Rouge: Louisiana State University Press, pp. 263-280.

Dür, A. (2007), 'Foreign Discrimination, Protection for Exporters, and U.S. Trade Liberalization', International Studies Quarterly, 51(2): 457-480.

Eckes, A. (1995), Opening America's Market: U.S. Foreign Trade Policy Since 1776, Chapel Hill and London: UNC Press.

George, A. and A. Bennett (2005), Case Studies and Theory Development in the Social Sciences, Cambridge: MIT Press.

Goldstein, J. (1993), Ideas, Interests, and American Trade Policy, Ithaca and London: Cornell University Press.

Goldstein, J. and R. Gulotty (2016), 'The Limits of Institutional Reform in the United States and the Global Trade Regime', in O. Fioretos, T. Faletti and A. Sheingate (eds), The Oxford Handbook of Historical Institutionalism, New York: OUP, pp. 611-626.

Hall, P., ed, (1989), The Political Power of Economic Ideas: Keynesianism across Nations. Princeton: PUP.

Hall, P. (2016), 'Politics as a Process Structured in Time and Space', O. Fioretos, T. Faletti, and A. Sheingate (eds), The Oxford Handbook of Historical Institutionalism, Oxford: OUP, pp. 31-50.

Hall, P. and R. Taylor (1996), 'Political Science and the Three New Institutionalisms', Political Studies, 44(5): 936-957.

Hay, C. (2006), 'Constructivist Institutionalism', in R. Rhodes, S. Binder and B. Rockman (eds), The Oxford Handbook of Political Institutions, New York: OUP, pp. 56-74.

Hay, C. (2011), 'Ideas and the Construction of Interests', in D. Béland and R. H. Cox (eds), Ideas and Politics in Social Science Research, New York: OUP, pp. 65-82.

Hay, C. and D. Wincott (1998), 'Structure, Agency and Historical Institutionalism', Political Studies, 46(5): 951-957.

Hodgson, G. (2006), 'What Are Institutions?', Journal of Economic Issues, XL(1): 1-25.

Huempfer, S. (2016), 'Burdens of a creditor nation: Business elites and the transformation of US trade policy, 1917-62', DPhil diss., Oxford University.

Irwin, D. (2017), Clashing over Commerce: A History of US Trade Policy, Chicago and London: UCP.

Keohane, R. (1984), After Hegemony: Cooperation and Discord in the World Political Economy, Princeton: PUP.

Köstem, S. (2017), 'When Can Idea Entrepreneurs Influence Foreign Policy? Explaining the Rise of the "Turkic World" in Turkish Foreign Policy', Foreign Policy Analysis, 13(3): 722-740.

Krasner, S. (1976), 'State Power and the Structure of International Trade', World Politics, 28(3): 317-347.

Lieberman, R. (2002), 'Ideas, Institutions, and Political Order: Explaining Political Change', American Political Science Review, 96(4): 697-712.

Mahoney, J. (2010), 'After KKV: The New Methodology of Qualitative Research', World Politics, 62(1): 120-147.

Mahoney, J and K. Thelen, eds (2010), Explaining Institutional Change: Ambiguity, Agency and Power. New York: CUP.

Markey-Towler, B. (2019), 'The Competition and Evolution of Ideas in the Public Sphere: A New Foundation for Institutional Theory', Journal of Institutional Economics, 15(1): 27-48.

McCloskey, D. N. (2016), Bourgeois Equality: How Ideas, Not Capital or Institutions, Enriched the World, Chicago and London: University of Chicago Press.

Morrison, J. A. (2012), 'Before Hegemony: Adam Smith, American Independence, and the Origins of the First Era of Globalization', International Organization, 66(3): 395-428.

Morrison, J. A. (2016), 'Shocking Intellectual Austerity: The Role of Ideas in the Demise of the Gold Standard in Britain', International Organization, 70(1): 175-207. 
Mukherji, R. (2013), 'Ideas, Interests, and the Tipping Point: Economic Change in India', Review of International Political Economy, 20(2): 363-389.

Niskanen, W. ([1971]2007), Bureaucracy and Representative Government, London and New York: Routledge.

Parsons, C. (2007), A Certain Idea of Europe, Ithaca and London: Cornell University Press.

Pastor, R. (1980), Congress and the Politics of U.S. Foreign Economic Policy, 1929-1976, Berkeley and Los Angeles: University of California Press.

Paterson, T. (1989), 'Introduction: John F. Kennedy's Quest for Victory and Global Crisis', in T. Paterson (ed.), Kennedy's Quest for Victory: American Foreign Policy 1961-1963, New York: OUP, pp. 3-23.

Preeg, E. (1970), Traders and Diplomats, Washington, DC: The Brookings Institution.

Rogowski, R. (1989), Commerce and Coalitions: How Trade Affects Domestic Political Alignments, Princeton: PUP.

Schmidt, V. (2008), 'Discursive Institutionalism: The Explanatory Power of Ideas and Discourse', Annual Review of Political Science, 11(1): 303-326.

Schmidt, V. (2011), 'A Curious Constructivism: A Response to Professor Bell', British Journal of Political Science, 42(3): 705-713.

Schmidt, V. (2017), 'Britain-out and Trump-in: A Discursive Institutionalist Analysis of the British Referendum on the EU and the US Presidential Election', Review of International Political Economy, 24(2): 248-269.

Sikkink, K. (1991), Ideas and Institutions: Developmentalism in Brazil and Argentina, Ithaca: Cornell University Press.

Slater, D. and E. Simmons (2010), 'Informative Regress: Critical Antecedents in Comparative Politics', Comparative Political Studies, 43(7): 886-917.

Soifer, D. (2012), 'The Causal Logic of Critical Junctures', Comparative Political Studies, 45(12): 1572-1597.

Viner, J. (1961), 'Economic Foreign Policy on the New Frontier', Foreign Affairs, 39(4): 560-577.

Weir, M. (1989), 'Ideas and Politics: The Acceptance of Keynesianism in Britain and the United States', in P. Hall (ed.), The Political Power of Economic Ideas: Keynesianism across Nations, Princeton: PUP, pp. 53-86.

Widmaier, W. (2016), Economic Ideas in Political Time: The Rise and Fall of Economic Orders from the Progressive Era to the Global Financial Crisis, Cambridge: CUP.

Widmaier, W., M. Blyth and L. Seabrooke (2007), 'Exogenous Shocks or Endogenous Constructions? The Meanings of Wars and Crises', International Studies Quarterly, 51(4): 747-759.

Winand, P. (1997a), 'American “Europeanists”, Monnet's Action Committee and British Membership', in G. Wilkes (ed.), Britain's Failure to Enter the European Community, 1961-63: The Enlargement Negotiations and Crises in European, Atlantic and Commonwealth Relations, Oxon and New York: Routledge, pp. 164-190.

Winand, P. (1997b), Eisenhower, Kennedy, and the United States of Europe (2nd edn), Basingstoke and London: Macmillan. Woods, N. (1995), 'Economic Ideas and International Relations: Beyond Rational Neglect', International Studies Quarterly, 39 (2): 161-180.

Zeiler, T. (1992), American Trade and Power in the 1960s, New York: Columbia University Press.

Cite this article: McAdam M (2022). Making ideas actionable in institutionalism: the case of trade liberalization in Kennedy's foreign economic policy. Journal of Institutional Economics 18, 827-841. https://doi.org/10.1017/S1744137421000849 